\section{Paying the price of peace}

\section{Boston}

US university programmes for the study of arms control and international security may be becoming casualties of the very decrease in superpower tensions that many of the programmes' researchers have long advocated. While some of the directors of academic programmes in arms control and security studies around the United States say that they have yet to experience a downturn in funding, they are virtually unanimous in their expectation of such a drop. Many have already field put it "everything on my bookshelf is out of date."

Harvey Sapolsky, who heads the Defense and Arms Control Studies Program at the Massachusetts Institute of Technology (MIT), echoes the sentiments of many of his counterparts when he says that the private foundations that have traditionally funded the field tend increasingly to "see security issues as being solved" by recent world developments. wisdom is overturned." lawyers and security experts. begun to respond by seeking to broaden their missions. As one researcher in the

"On the contrary", Sapolsky argues, "we think that many of these issues are more exciting than ever now as the theology is challenged and forty years of accepted

Sapolsky says he hopes foundations realize the extent of "important work" left to be done in the field - questions about "what in the military should be shrunk and by how much", and assessments of potential "threats posed by the new international circumstances". Sapolsky stresses that his programme, like others, has begun to consider a broadened notion of security. Current plans include a proposed collaboration between environmental scientists,

The reduction in funding for university programmes in arms control and security issues will mark the end of more than two decades of growth. In the United States, private funding for these programmes began in the late 1960s when the Ford Foundation, under the direction of former White House security adviser McGeorge Bundy, provided several large grants.

\section{No madness in UK policy}

\section{London}

UK agriculture minister John Gummer's often-repeated assertion that "beef is safe" is endorsed in a report from an allparty House of Commons committee investigating the epidemic of bovine spongiform encephalopathy (BSE) in British cattle, published last week. The agriculture select committee also concludes that the UK government's reaction to BSE represents a "substantial improvement" on its handling of the 1988 salmonella outbreak in British eggs - that food scare forced the resignation of a junior health minister and brought criticism from the agriculture committee.

But the report suggests that some action, notably banning certain cattle offals for human consumption and providing full compensation to farmers for BSE-afflicted cattle, could have been taken more quickly.

In a departure from tradition, the committee singled out one witness for attack. Professor Richard Lacey, a University of Leeds microbiologist, told the committee that "we could virtually lose a generation of people" through BSE. The report describes his evidence as "a mixture of science and science fiction", and criticizes the UK media for the extensive coverage given to "the pronouncements of one or two irresponsible scientists", which fuelled public anxiety over the risks to human health.

Gummer has rightly relied on advice tists "rather than negotiating with vested interests", the report says; but he should be prepared to go beyond those measures justified on scientific grounds alone, to reassure the public or for commercial reasons.

The report goes on to recommend a number of further precautionary countermeasures. The ban on human consumption of specified offals should apply to all cattle and splitting of cattle heads to remove the brain, should be banned. Although practised in only a small minority of UK abattoirs, several witnesses to the committee were concerned that this could spray an aerosol of potentially infective brain tissue over the head meat.

Other suggested countermeasures are based around the possibility that BSE may be transmissible vertically, from cow to calf. Calls for a ban on breeding from the offspring of BSE cases are rejected, consistent with advice from the government's independent scientific advisory committee. But the report suggests that this breeding should be discouraged: if $\mathrm{BSE}$ occurs as a result of vertical transmission, farmers should not be eligible for compensation. To ensure that the offspring of BSE cases can be tracked down if vertical transmission is shown to be possible, the report recommends that a central computer record of cattle breeding and movement should be set up (see Nature 345, 277;24 May 1990). from an independent committee of scien-
Many of the same foundations are shifting their focus away from traditional studies of defence and arms control towards the environment and development issues in Eastern Europe and developing countries.

But is current confidence in international stability well grounded? John Mearsheimer, who heads the political science department at the University of Chicago, predicts that the coming fall in funding will be only a "brief lull" based upon "false optimism" about global stability. Issues such as the potential proliferation of nuclear weapons in Europe, Mearsheimer predicts, will create "very serious trouble" for international relations and are likely to renew foundation support to the field. In the meantime, Mearsheimer calls the inclination of many of his colleagues to broaden the definition of security to include ecological and other concerns "an assault" on the field.

Paul Walker, director of the Institute for Peace and International Security based in Cambridge, Massachusetts, says that the funding situation is presenting immediate problems for smaller organizations. Walker expresses dismay that foundations are turning to other areas because the current situation presents a "marvelous opportunity" to establish new security arrangements. Major cuts in defence spending and uncertainty over the future of the North Atlantic Treaty Organization will require a fundamental rethinking of military roles, he says.

Walker, who is also a graduate of MIT's arms control programme, complains that the current funding climate has also fostered a willingness to approach "inappropriate" funding sources. MIT's programme, for example, has appealed to defence contractors for general support for the first time in its history. Sapolsky claims that such funding will not hamper the programme's independence, but Walker calls the move "outrageous," likening it to "lung cancer researchers appealing to cigarette manufacturers" to support their work.

Coit Blacker, a professor of international relations at the University of Southern California and former associate director of Stanford's Center on International Security and Arms Control, acknowledges many of the problems, but puts them in a more positive light. Blacker stresses that those programmes that are "most responsive" to current shifts in the priorities of the field will be best able to survive the current funding climate. Like Mearsheimer, Blacker espouses the view that the past four decades have presented "an atypically quiet period in world politics" because of the relatively stable, "bipolar competition" between the United States and the Soviet Union. Now, with an increasingly "multi-polar world", he says, "the potential for international violence is increased".

Seth Shulman 